\title{
A Multicenter Study to Clarify the Optimal HCV-RNA Negative Period during Combined Therapy with Pegylated Interferon Plus Ribavirin in Patients with Chronic Hepatitis Caused by HCV Genotype 2
}

\author{
Sumiko Nagoshi ${ }^{1}$, Yohei Koshima ${ }^{2}$, Ikuo Nakamura ${ }^{3}$, Junji Funyu ${ }^{4}$, Chuichi Sekine ${ }^{5}$, \\ Youji Harada ${ }^{6}$, Ko Nishikawa ${ }^{7}$, Takeshi Yoshida ${ }^{8}$, Atsushi Matsui ${ }^{9}$, Naoki Sotome ${ }^{10}$, \\ Kenichi Toshima ${ }^{11}$, So Takegoshi ${ }^{12}$, Masao Shiomi ${ }^{13}$, Masahiko Tanaka ${ }^{14}$, Akira Saito ${ }^{15}$, \\ Kenji Fujiwara ${ }^{16}$ and Satoshi Mochida ${ }^{1}$
}

\begin{abstract}
Objective A multicenter open trial was performed to clarify the optimal duration of combined pegylated interferon (Peg-IFN) plus ribavirin therapy in patients with chronic hepatitis caused by HCV genotype 2 .

Methods A total of 100 patients seen between 2005 and 2007 received the combination therapy for 4 to 52 weeks. The cutoff value of the HCV-RNA-negative (titers under $1.7 \mathrm{Log} \mathrm{IU} / \mathrm{mL}$ ) period during the therapy to predict sustained virological response (SVR) was determined by ROC curve and multivariate logistic regression analyses. The result was validated in 48 patients between 2008 and 2009.

Results SVR was achieved in 78 patients. Serum HCV-RNA titers decreased to less than $1.7 \mathrm{Log}$ IU/mL at 4 weeks of the therapy in 60 patients. The SVR rate in these patients was $85 \%$, which was significantly higher than that of remaining 40 patients with a SVR rate of $68 \%$. An HCV-RNA-negative period of $\geq 17$ weeks was selected as the cutoff value, which showed a significant odds ratio of 4.77 for SVR. Among the 35 patients who showed a decrease of the serum HCV-RNA of less than $1.7 \mathrm{Log}$ IU/mL between 8 and 16 weeks of therapy, the SVR rate was significantly higher in 16 patients with a serum HCV-RNA-negative period of $\geq 17$ weeks (94\%) than in 19 patients in whom the period was less than 17 weeks $(63 \%)$. Similar results were obtained in the subsequent validation study.

Conclusion Prolonged combined Peg-IFN plus ribavirin therapy, with an HCV-RNA-negative period of $\geq 17$ weeks, yielded good therapeutic outcomes in patients with chronic HCV genotype 2 hepatitis.
\end{abstract}

Key words: chronic hepatitis, HCV, genotype 2, pegylated interferon, ribavirin, sustained virological response, rapid virological response

(Intern Med 51: 9-15, 2012)

(DOI: 10.2169/internalmedicine.51.6237)

\section{Introduction}

Combined pegylated interferon (Peg-IFN) plus ribavirin therapy is the standard therapy for patients with chronic hepatitis caused by both hepatitis $\mathrm{C}$ virus (HCV) genotypes 1 and 2. Sustained virological response (SVR), which refers to undetectable serum HCV-RNA at 24 weeks after the dis-

\footnotetext{
${ }^{1}$ Department of Gastroenterology \& Hepatology, Saitama Medical University, Japan, ${ }^{2}$ Saitama Red Cross Hospital, Japan, ${ }^{3}$ Saitama Medical Center, Jichi Medical University, Japan, ${ }^{4}$ Chichibu Hospital, Japan, ${ }^{5}$ Saiseikai Kawaguchi General Hospital, Japan, ${ }^{6}$ Toda Chuo General Hospital, Japan, ${ }^{7}$ Ageo Central General Hospital, Japan, ${ }^{8}$ Saitama Social Insurance Hospital, Japan, ${ }^{9}$ Shisei Hospital, Japan, ${ }^{10}$ Kumagaya General Hospital, Japan, ${ }^{11}$ Musashiranzan Hospital, Japan, ${ }^{12}$ Asakadai Central General Hospital, Japan, ${ }^{13}$ Shiomi Hospital, Japan, ${ }^{14}$ Kanetsu Hospital, Japan, ${ }^{15}$ Nishisaitama-chuo National Hospital, Japan and ${ }^{16}$ Japan Labour Health and Welfare Organization, Yokohama Rosai Hospital, Japan Received for publication July 22, 2011; Accepted for publication September 15, 2011 Correspondence to Dr. Satoshi Mochida, smochida@saitama-med.ac.jp
} 
continuation of therapy, is obtained in about $50 \%$ of patients with HCV genotype 1 infection following combined PegIFN plus ribavirin therapy for 48 weeks (1), while the therapeutic outcome appears to be superior in patients with $\mathrm{HCV}$ genotype 2 infection, in whom a SVR rate of about $80 \%$ has been reported even after the therapy for 24 weeks (1-3).

Rapid virological response (RVR) and complete early virological response (cEVR), defined as serum HCV-RNA titers of less than $1.7 \mathrm{Log} \mathrm{IU} / \mathrm{mL}$ at 4 weeks and 12 weeks, respectively, during Peg-IFN plus ribavirin therapy, are known to be useful predictors of the outcome of chronic hepatitis caused by HCV genotype 1 and 2 (1, 4-6). According to previous reports, SVR was achieved after Peg-IFN plus ribavirin therapy for 48 weeks in about $90 \%$ and 80 to $88 \%$ of patients with $\mathrm{HCV}$ genotype 1 infection showing RVR and cEVR, respectively $(1,4,5,7)$. Patients without RVR and cEVR showed an inferior therapeutic outcome as compared to those who showed RVR and cEVR after equivalent durations of the combined therapy, with SVR rates of $44 \%$ and $17 \%$, respectively (5). Also, in patients with HCV genotype 2 infection, SVR was achieved after 24 weeks of Peg-IFN plus ribavirin therapy in greater than $80 \%$ of the patients who showed RVR, whereas the SVR rates ranged between $48 \%$ and $77 \%$ in those who did not show RVR (1, 3, 8-11). Thus, therapeutic improvements are required to improve the SVR rates in patients not showing RVR, with HCV genotype 2 infection, and in those not showing cEVR, with HCV genotype 1 infection.

Recently, response-guided therapy has been applied worldwide for chronic hepatitis patients with HCV genotype 1 infection receiving Peg-IFN plus ribavirin therapy. Prolongation of the therapeutic period from 48 weeks to 72 weeks has been reported to increase the SVR rate in patients with HCV genotype 1 who failed to achieve cEVR (5), when they achieved at least a 2-log decrease of serum HCV-RNA titers of that at the baseline at 12 weeks of therapy and showed undetectable HCV-RNA until 24 weeks (12). Based on these observations, prolongation of the duration of PegIFN plus ribavirin therapy to 72 weeks was approved in Japan in 2009, but only in patients fulfilling all of the following virological conditions; 1) HCV genotype 1 infection, 2) serum HCV-RNA titers of $\geq 5.0 \mathrm{Log} \mathrm{IU} / \mathrm{mL}$ at the baseline, 3) no cEVR, but reduction of the serum HCV-RNA titer to $<1 / 100$ of that at the baseline at 12 weeks of therapy, 4) undetectable serum HCV-RNA by 36 weeks of the therapy.

In contrast, in patients with $\mathrm{HCV}$ genotype 2 infection, the SVR rates were shown to be equivalent, if RVR was achieved, between patients receiving Peg-IFN plus ribavirin therapy for 24 weeks and those receiving the therapy for 12 to 16 weeks $(3,8-10)$. Thus, short-term therapies merit consideration for patients with HCV genotype 2 infection, since they would be associated with reduced financial cost as well as reduced incidence of adverse reactions to the drugs. On the other hand, it is uncertain whether prolongation of the duration of Peg-IFN plus ribavirin therapy may improve the SVR rate in patients with HCV genotype 2 infection who fail to show RVR. Therefore, we performed this multicenter open trial to clarify the efficacy of prolonged duration of Peg-IFN plus ribavirin therapy for chronic hepatitis patients with HCV genotype 2 infection.

\section{Materials and Methods}

\section{Patients \& therapies}

The subjects were 148 Japanese patients with chronic hepatitis caused by HCV genotype 2 who were recruited at 15 institutions with hepatologists in Saitama Prefecture (Saitama Pegylated Interferon Study Group) between October 2005 and September 2009, and received combined Peg-IFN plus ribavirin therapy. The patients were classified into 2 groups; 100 patients seen before December 2007 (estimation cohort) and 48 patients seen after January 2008 (validation cohort); the cutoff HCV-RNA-negative period to discriminate between patients who would and would not show SVR was determined in the former cohort and an analysis to validate the results obtained was conducted in the latter cohort. The diagnosis of chronic hepatitis was made based on the histological findings in liver biopsy specimens and/or serum biochemical tests and peripheral blood cell counts.

Peg-IFN $\alpha-2 b$ (Peg-Intron, MSD.K.K., Tokyo, Japan) was administered by subcutaneous injection at the dose of 1.2$1.5 \mu \mathrm{g} / \mathrm{kg}$ body weight once a week in combination with ribavirin (Rebetol, MSD.K.K.), administered orally daily at the dose of 600 to $1,000 \mathrm{mg}$, depending on the body weight (600, 800 and $1,000 \mathrm{mg}$ for those with a body weight of less than $60 \mathrm{~kg}$, between 60 and $80 \mathrm{~kg}$ and greater than 80 $\mathrm{kg}$, respectively). The doses of Peg-IFN and ribavirin were reduced, as needed, depending on the peripheral blood cell counts during the therapy. The therapy was administered for 24 weeks, but was discontinued earlier if severe adverse reactions to Peg-IFN and/or ribavirin developed. The duration of therapy was prolonged for up to 52 weeks as per request of the patients.

Written informed consent was obtained from all of the patients before their enrollment in the study, which was conducted with the approval of the Institutional Review Board of Saitama Medical University Hospital.

\section{Determination of serum HCV genotype and HCV- RNA titers}

HCV genotype was determined using HCV GENOTYPE Primer Kit (Institute of Immunology Co., Ltd., Tokyo, Japan) in 46 patients and Immucheck F-HCV Gr 'Kokusai' (Sysmex Co., Kobe, Japan) in 102 patients. HCV was diagnosed as genotype 2 when the serotype was classified as group 2 with the latter kit.

Serum HCV-RNA titers at the initiation of therapy were measured with the commercial kit COBAS AMPLICOR HCV Test, v2.0 (Roche Diagnostics K.K., Tokyo, Japan) in the estimation cohort. In this cohort, the titers during and following the therapy were evaluated with the kit COBAS 
Table 1. Demographic and Clinical Characteristics of the Patients with Chronic Hepatitis Caused by HCV Genotype 2 before Pegylated Interferon Plus Ribavirin Therapy

\begin{tabular}{lcc}
\hline variable & estimation group $(\mathrm{n}=100)$ & validation group $(\mathrm{n}=48)$ \\
\hline age* (years) & $55(30-75)$ & $59(30-74)$ \\
sex (male : female) & $52: 48$ & $18: 30$ \\
outcome of previous interferon therapy & & 40 \\
$\quad$ treatment-naïve & 81 & 5 \\
$\quad$ relapse & 10 & 1 \\
$\quad$ non-response & 4 & 1 \\
$\quad$ outcome of therapy: unknown & 4 & 1 \\
$\quad$ therapy and its outcome: unknown & 1 & $46(10-354)$ \\
HCV-RNA titer* & $1,250(7-5,100) \mathrm{KIU} / \mathrm{mL}$ & $6.4(3.4-7.5) \mathrm{LogIU} / \mathrm{mL}$ \\
ALT $(\mathrm{IU} / \mathrm{L})^{*}$ & $60(10-486)$ & $5,265(2,490-8,370)$ \\
WBC $(/ \mu \mathrm{L})^{*}$ & $5,300(2,150-9,800)$ & $13.5(11.5-17.5)$ \\
$\mathrm{Hb}(\mathrm{g} / \mathrm{dL})^{*}$ & $14.5(10.3-17.5)$ & $19.1(8.0-33.7)$ \\
Platelet $\left(\times 10^{4} / \mu \mathrm{L}\right)^{*}$ & $18.1(7.0-31.9)$ & $*$ median $($ minimum $-\mathrm{maximum})$
\end{tabular}

AMPLICOR HCV Test, v2.0 until 2007 and the kit COBAS AmpliPrep/COBAS TaqMan HCV Test (Roche Diagnostics K.K.) at 2008 and later. In contrast, in the validation cohort, the titers were measured with the kit COBAS AmpliPrep/ COBAS TaqMan HCV Test. Serum HCV-RNA was judged as "negative" when the titers were less than $1.7 \mathrm{Log} \mathrm{IU} / \mathrm{mL}$ by the COBAS AmpliPrep/COBAS TaqMan HCV Test (identical to undetectable levels by the COBAS AMPLICOR HCV Test, v2.0) during Peg-IFN plus ribavirin therapy, and patients showing titers $1.7 \mathrm{Log} \mathrm{IU} / \mathrm{mL}$ or less at 4 weeks of the therapy were classified as showing RVR. In contrast, patients were judged as showing SVR when the serum HCVRNA remained undetectable continuously for at least 24 weeks after discontinuation of therapy, as assessed by either COBAS AMPLICOR HCV Test, v2.0 or COBAS AmpliPrep/COBAS TaqMan HCV Test.

\section{Statistical analysis}

The demographic and clinical features of the patients showing SVR were evaluated by Fisher's exact test. The cutoff HCV-RNA-negative period during the therapy to predict SVR was determined through a receiver operating characteristic (ROC) curve analysis, as the point at which the sum of (1-sensitivity) $)^{2}$ and (1-specificity) $)^{2}$ was the minimum. The significance of the cutoff value was assessed by multivariate logistic regression analysis in a stepwise manner. pvalues of less than 0.05 were considered to indicate statistical significance. All of these analyses were performed using SAS version 9.2 (SAS Institute Inc., Cary, NC, USA) and Medcalc version 11.5.1.0 for Windows (Medcalc Software, Mariakerke, Belgium).

\section{Results}

\section{Demographic and clinical features of patients}

The demographic and clinical features of the patients are shown in Table 1. There were a total of 148 patients consisting of 70 men and 78 women, aged between 30 and 75 years old. 25 patients (17\%) had a previous history of interferon therapy and the therapeutic outcome was "relapse" and "non-response" in 15 and 5 patients, respectively. No significant differences in demographic features or serum ALT levels and peripheral blood cells counts before therapy were found between the 100 patients in the estimation cohort and 48 patients in the validation cohort.

Serum HCV-RNA titers immediately before the start of the Peg-IFN plus ribavirin therapy ranged from 7 to 5,100 $\mathrm{KIU} / \mathrm{mL}$ in the estimation cohort and from 3.4 to $7.5 \mathrm{Log}$ $\mathrm{IU} / \mathrm{mL}$ in the validation cohort. The titers were less than $100 \mathrm{KIU} / \mathrm{mL}$ in 7 patients in the former cohort and less than $5 \mathrm{Log} \mathrm{IU} / \mathrm{mL}$ in 5 patients in the latter cohort, and were not examined in 2 and 4 patients, respectively. Consequently, the serum HCV-RNA titers were $100 \mathrm{KIU} / \mathrm{mL}$ or more in the 91 patients $(91 \%)$ in the estimation cohort and $5.0 \mathrm{Log}$ $\mathrm{IU} / \mathrm{mL}$ or more in 39 patients $(81 \%)$ in the validation cohort immediately before the start of the Peg-IFN plus ribavirin therapy.

\section{Outcome in the estimation cohort after the Peg-IFN plus ribavirin therapy}

It was necessary to discontinue the Peg-IFN plus ribavirin therapy within 17 weeks due to the appearance of severe adverse reactions such as depressiveness, retinopathy, generalized fatigue, nausea or hemolytic anemia in 6 patients, and for personal reasons in 4 patients. In the remaining 90 patients, the therapy was continued for 20 to 24 weeks (67 patients), or 25 to 52 weeks (23 patients). It was necessary to reduce the dose of Peg-IFN to less than $1.2 \mu \mathrm{g} / \mathrm{kg}$ body weight in 28 patients and the dose of ribavirin to less than 8 $\mathrm{mg} / \mathrm{kg}$ body weight in 27 patients.

Serum HCV-RNA titers became less than $1.7 \mathrm{Log} \mathrm{IU} / \mathrm{mL}$, that is, to levels undetectable by the COBAS AMPLICOR HCV Test, v2.0, after 4, 8, 12 and 16 weeks of therapy in $60,27,5$ and 3 patients, respectively. SVR was achieved in 78 patients (78\% by intention-to-treat analysis), and the SVR rate in the 60 patients showing RVR was $85 \%$, which was significantly higher than the SVR rate of $68 \%$ in the re- 


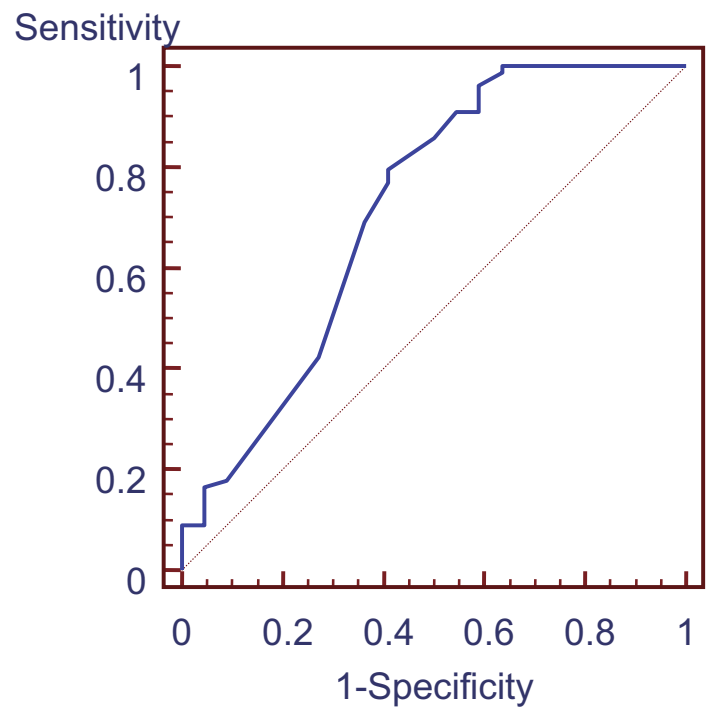

Figure 1. ROC curve of the serum HCV-RNA-negative periods during Peg-IFN plus ribavirin therapy to predict SVR in chronic hepatitis patients with HCV genotype 2 infection. $\mathrm{AUC}=0.715$ with $95 \%$ confidence interval from 0.616 to 0.801 , $\mathrm{p}=\mathbf{0 . 0 0 2 9}$.

maining 40 patients who did not exhibit RVR $(\mathrm{p}<0.05)$. The SVR rates were $80 \%(4 / 5), 85 \%(44 / 52), 100 \%(2 / 2)$ and $100 \%(1 / 1)$ in patients showing RVR when the rates were evaluated depending on serum HCV-RNA-negative periods; less than 16 weeks, 17 to 24 weeks, 25 to 32 weeks and 41 to 48 weeks, respectively. The rates were $60 \%(9 / 15), 100 \%$ $(7 / 7)$ and $100 \%(5 / 5)$, respectively, in those achieving negative HCV-RNA at 8 weeks with serum HCV-RNA-negative periods of less than 16 weeks, 17 to 24 weeks and 25 to 32 weeks. The rates were $75 \%(3 / 4), 67 \%(2 / 3)$ and $100 \%$ (1/ 1), respectively, in those achieving negative HCV-RNA at 12 weeks or later with serum HCV-RNA-negative periods of less than 16 weeks, 25 to 32 weeks and 33 to 40 weeks.

\section{Factors associated with the therapeutic efficacy of Peg-IFN plus ribavirin therapy in the estimation co- hort}

Serum HCV-RNA-negative period was examined in 100 patients, including 5 patients, in which the serum HCV-RNA titers remained greater than $1.7 \mathrm{Log} \mathrm{IU} / \mathrm{mL}$ throughout the treatment period. The ROC curve analysis revealed that the serum HCV-RNA-negative period during the therapy was a significant factor associated with the SVR; the area under the ROC curve (AUC) was 0.715, with a p-value of 0.0029 , when the value was compared to the AUC of 0.5 by the $\mathrm{z}$ test (Fig. 1). The optimal cutoff value of the serum HCVRNA-negative period that can discriminate between patients who would and would not achieve SVR was calculated as 17 weeks, with a sensitivity and specificity of 0.79 and 0.59 , respectively (Table 2 ).

Thus, the factors potentially associated with SVR were examined in the estimation cohort including the serum HCV-RNA-negative period of $\geq 17$ weeks as one of the
Table 2. Cutoff Values of the Serum HCV-RNA-Negative Period during Pegylated Interferon Plus Ribavirin Therapy to Predict the Outcome in Chronic Hepatitis Patients with HCV Genotype 2 in the Estimation Cohort

\begin{tabular}{ccccc}
\hline $\begin{array}{c}\text { Cutoff value } \\
\text { (weeks) }\end{array}$ & Sensitivity & Specificity & +LR & -LR \\
\hline 12 & 0.96 & 0.41 & 1.63 & 0.094 \\
13 & 0.92 & 0.41 & 1.56 & 0.19 \\
14 & 0.91 & 0.41 & 1.54 & 0.22 \\
15 & 0.91 & 0.45 & 1.67 & 0.20 \\
16 & 0.86 & 0.50 & 1.72 & 0.28 \\
17 & 0.79 & 0.59 & 1.94 & 0.35 \\
18 & 0.77 & 0.59 & 1.88 & 0.39 \\
19 & 0.69 & 0.64 & 1.90 & 0.48 \\
20 & 0.42 & 0.73 & 1.55 & 0.79 \\
21 & 0.18 & 0.91 & 1.97 & 0.90 \\
22 & 0.17 & 0.95 & 3.67 & 0.87 \\
24 & 0.15 & 0.95 & 3.38 & 0.89 \\
25 & 0.14 & 0.95 & 3.10 & 0.90 \\
26 & 0.13 & 0.95 & 2.82 & 0.91 \\
27 & 0.10 & 0.95 & 2.26 & 0.94 \\
\hline
\end{tabular}

+LR: likelihood ratio of a positive test, -LR: likelihood ratio of a negative test

variables. Univariate analysis identified the following factors exerting a significant influence on the SVR rate; the serum HCV-RNA-negative period of 17 weeks or more, age 55 years or more, peripheral platelet count of $13 \times 10^{4} / \mu \mathrm{L}$ or more, Peg-IFN dose of $1.2 \mu \mathrm{g} / \mathrm{kg}$ body weight/week or more, and ribavirin dose of $8 \mathrm{mg} / \mathrm{kg}$ body weight/day or more (Table 3). Then, multivariate analysis was performed in a stepwise manner using these 5 variables plus the hemoglobin concentration at the baseline, which identified a serum HCV-RNA-negative period of $\geq 17$ weeks (odds ratio [OR] of 4.77 with $95 \%$ confidence interval [CI] from 1.37 to 16.61 ) and ribavirin dose of $8 \mathrm{mg} / \mathrm{kg}$ body weight/day or more (OR: 6.28, 95\% CI: 1.89-20.84) as significant factors independently associated with SVR (Table 4).

\section{Significance of the serum HCV-RNA-negative period in patients of the estimation and validation cohorts receiving Peg-IFN plus ribavirin therapy}

The significance of the serum HCV-RNA-negative period was evaluated in the 35 patients of the estimation cohort who did not show RVR except that serum HCV-RNA titers decreased less than 1.7 Log IU/mL during the Peg-IFN plus ribavirin therapy (Fig. 2). Serum HCV-RNA titers decreased to under $1.7 \mathrm{Log} \mathrm{IU} / \mathrm{mL}$ between 8 and 16 weeks of therapy in these patients. The SVR rate in 16 patients with serum HCV-RNA-negative period of $\geq 17$ weeks was $94 \%$ (15/16), significantly higher than the rate $(63 \% ; 12 / 19)$ in the remaining 19 patients with serum HCV-RNA-negative period of $<17$ weeks.

Similar evaluations were conducted in the 48 patients of the validation cohort (Table 5). The serum HCV-RNA titers decreased to less than $1.7 \mathrm{Log} \mathrm{IU} / \mathrm{mL}$ at 4 weeks during the Peg-IFN plus ribavirin therapy in 35 of the 48 patients (RVR rate, 73\%). Among these patients, 25 and 9 patients received the Peg-IFN plus ribavirin therapy between 21 and 24 weeks and between 25 and 48 weeks, respectively. In re- 
Table 3. Univariate Analysis to Identify Factors Associated with SVR after Pegylated Interferon Plus Ribavirin Therapy in Chronic Hepatitis Patients with HCV Genotype 2 in the Estimation Cohort

\begin{tabular}{llcccc}
\hline Factor & & $\mathrm{n}$ & No. of SVR & SVR rate $(\%)$ & $\mathrm{p}$ value \\
\hline HCV-RNA-negative duration during & $<17$ & 29 & 16 & 45.2 & $<0.001$ \\
therapy (weeks) & $\geq 17$ & 71 & 62 & 87.3 & \\
Age (years) & $<55$ & 50 & 44 & 88.0 & 0.028 \\
& $\geq 55$ & 50 & 34 & 68.0 & \\
Sex & Male & 52 & 43 & 82.7 & 0.236 \\
& Female & 47 & 34 & 72.3 & \\
HCV-RNA $(\mathrm{KIU} / \mathrm{mL})$ & $<1,000$ & 42 & 36 & 85.7 & 0.213 \\
& $\geq 1,000$ & 56 & 41 & 73.2 & \\
ALT $(\mathrm{IU} / \mathrm{L})$ & $<60$ & 49 & 38 & 77.6 & 1.000 \\
& $\geq 60$ & 49 & 39 & 79.6 & \\
WBC $(/ \mu \mathrm{L})$ & $<5,000$ & 41 & 31 & 75.6 & 0.457 \\
Hb $(\mathrm{g} / \mathrm{dL})$ & $\geq 5,000$ & 56 & 46 & 82.1 & \\
& $<14$ & 33 & 22 & 66.7 & 0.066 \\
Platelet $\left(\times 10^{4} / \mu \mathrm{L}\right)$ & $\geq 14$ & 66 & 56 & 84.9 & \\
& $<13$ & 17 & 9 & 52.9 & 0.008 \\
Pegylated interferon & $\geq 13$ & 82 & 69 & 84.2 & \\
$(\mu \mathrm{g} / \mathrm{kg}$ body weight/week) & $<1.2$ & 28 & 17 & 60.7 & 0.005 \\
Ribavirin & $\geq 1.2$ & 66 & 58 & 87.9 & \\
$(\mathrm{mg} / \mathrm{kg}$ body weight/day) & $<8$ & 27 & 14 & 51.9 & $<0.001$ \\
& $\geq 8$ & 68 & 62 & 91.2 & \\
\hline
\end{tabular}

Table 4. Multivariate Analysis to Identify Factors Associated with SVR after Pegylated Interferon Plus Ribavirin Therapy in Chronic Hepatitis Patients with HCV Genotype 2 in the Estimation Cohort

\begin{tabular}{lccl}
\hline Factor & Odds Ratio & 95\% CI & p value \\
\hline HCV-RNA-negative duration during therapy (17 weeks or more) & 4.77 & $1.37-16.61$ & 0.014 \\
Ribavirin (8 mg/kg body weigt/day or more) & 6.28 & $1.89-20.84$ & 0.003 \\
Age (55 years or more) & 0.27 & $0.07-1.02$ & 0.053 \\
\hline CI: confidence interval & & &
\end{tabular}

maining 13 patients, the serum HCV-RNA titers decreased to less than $1.7 \mathrm{Log} \mathrm{IU} / \mathrm{mL}$ at 8 weeks of therapy. Among them, 11 patients received the therapy for 32 to 50 weeks. Consequently, the serum HCV-RNA-negative period was $\geq 17$ weeks in 45 patients (94\%). SVR was obtained in 41 patients $(85 \%)$ of the 48 patients of the validation cohort. The SVR rate in the 35 patients showing RVR was $89 \%$, which was almost equivalent to that $(82 \%)$ in the 11 patients receiving Peg-IFN plus ribavirin therapy, who did not show RVR but had a serum HCV-RNA-negative period of $\geq 17$ weeks.

\section{Discussion}

To determine the optimal duration of Peg-IFN plus ribavirin therapy for chronic hepatitis patients with $\mathrm{HCV}$ genotype 2 infection, the factors associated with SVR were evaluated in 100 patients seen between 2005 and 2007. Serum HCVRNA titers were measured by the COBAS AMPLICOR HCV Test, v2.0 and/or the COBAS AmpliPrep/COBAS TaqMan HCV Test. The ROC curve analysis followed by univariate and multivariate logistic regression analyses were performed, and a serum HCV-RNA-negative period of $\geq 17$ weeks during the Peg-IFN plus ribavirin therapy was se- lected as a crucial factor significantly associated with SVR. The significance of this serum HCV-RNA-negative period was validated in the 48 patients in the validation cohort seen between 2008 and 2009; the HCV-RNA titers in this cohort were measured by the COBAS AmpliPrep/COBAS TaqMan HCV Test, and the HCV-RNA-negative period (defined as the duration for which the HCV-RNA titers remained under 1.7 Log IU/mL, corresponding to undetectable levels by the COBAS AMPLICOR HCV Test, v2.0,) of $\geq 17$ weeks was similarly shown to affect the SVR rates in this cohort.

The univariate analysis revealed that the age of the patients, peripheral platelet count before the start of the PegIFN plus ribavirin therapy and the doses of Peg-IFN and ribavirin actually administered during the therapy were significantly associated with the SVR in the estimation cohort. Also, multivariate analysis demonstrated that a ribavirin dose of $8 \mathrm{mg} / \mathrm{kg}$ body weight or more was a significant factor independently associated with the SVR rate in addition to the serum HCV-RNA-negative period of $\geq 17$ weeks. It is well known that the dose of ribavirin, as well as that of Peg-IFN, are important factors affecting the efficacy of the Peg-IFN plus ribavirin therapy in patients with HCV genotype 1 infection (13), in which the response-guided therapy depending on the initial duration of serum HCV-RNA disap- 
pearance was universally done. Moreover, a previous metaanalysis of randomized controlled trials in patients with HCV genotype 2 or 3 infection showed that the combined therapy with Peg-IFN plus ribavirin administered at a dose of between 800 and 1,400 mg/day depending on the body weight of the patients produced superior therapeutic efficacy as compared to therapy with Peg-IFN plus ribavirin administered in a flat-dosing manner at $800 \mathrm{mg} /$ day (10). Thus, the significance of the doses of Peg-IFN and ribavirin as predictive factors to estimate the outcome of Peg-IFN plus ribavirin therapy should be further investigated in patients with $\mathrm{HCV}$ genotype 2 infection in relation to the serum HCVRNA-negative period during the therapy.

The results of the present trial propose the usefulness of response-guided Peg-IFN plus ribavirin therapy for patients with HCV genotype 2 infection, similar to the case for patients with HCV genotype 1 infection. The patients not showing RVR, but showing negative serum HCV-RNA at 8 weeks may achieve SVR following the Peg-IFN plus ribavi-

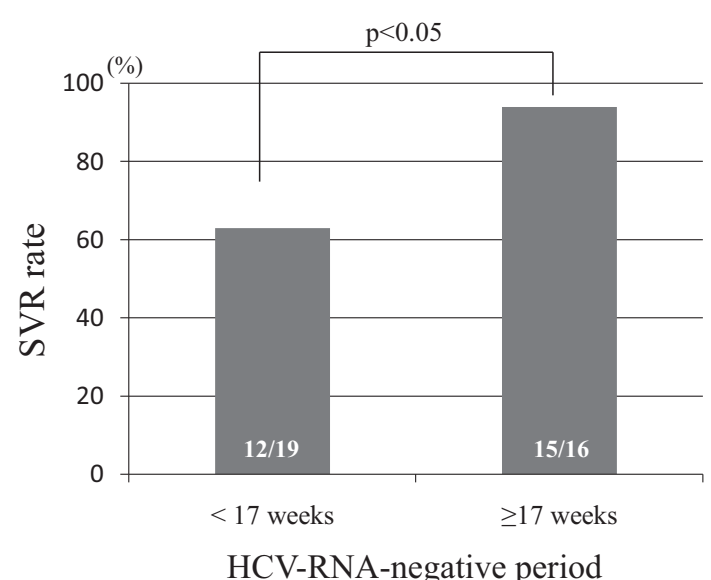

Figure 2. SVR rates in chronic hepatitis patients with $\mathrm{HCV}$ genotype 2 infection in whom the serum HCV-RNA titers decreased to less than $1.7 \log \mathrm{IU} / \mathrm{mL}$ between 8 and 16 weeks during Peg-IFN plus ribavirin therapy in the estimation cohort. The SVR rate was significantly higher in the patients in whom the serum HCV-RNA-negative period was $\geq 17$ weeks than in those in whom the period was less than 17 weeks. rin therapy for 25 weeks. Also, the therapy for 29 and 33 weeks has been recommended for patients showing disappearance of the serum HCV-RNA at 12 and 16 weeks of therapy, respectively. In contrast, patients showing RVR may achieve SVR following the therapy for only 21 weeks. These issues warrant a prospective investigation in a larger number of patients in the future.

It is noteworthy that the serum HCV-RNA-negative period was defined as the duration for which the serum HCV-RNA titers decreased to undetectable levels in the COBAS AMPLICOR HCV Test, v2.01, which were identical to those of less than $1.7 \mathrm{Log}$ IU/mL by the COBAS AmpliPrep/COBAS TaqMan HCV Test. In the present study, there were 28 patients in the validation cohort in whom serum HCV-RNA was detectable by the COBAS AmpliPrep/COBAS TaqMan HCV Test at 4 weeks of Peg-IFN plus ribavirin therapy (Table 5). Among them, 8 patients received the therapy between 16 and 24 weeks and 20 patients between 25 and 50 weeks. The resultant SVR rates were $63 \%$ and $85 \%$, respectively, in patients receiving the therapy for the standard and prolonged periods. Thus, Peg-IFN plus ribavirin therapy for prolonged periods is recommended for patients showing the serum HCV-RNA titers of greater than $1.7 \mathrm{Log} \mathrm{IU} / \mathrm{mL}$ at 4 weeks of therapy, but the significance of prolonged therapy for those showing detectable serum HCV-RNA by the COBAS AmpliPrep/COBAS TaqMan HCV Test should be further investigated in a large scale of patients.

Recently, genetic polymorphisms of the IL28B gene were shown to be a most crucial predictive factor to determine the outcome of Peg-IFN plus ribavirin therapy in patients with HCV genotype 1 infection (14-16). Therapeutic efficacy can be predicted based on alleles of IL28B generelated SNPs, as well as viral factors such as mutations of amino acids at core 70 and/or core 91 of HCV genotype $1(17,18)$. Also, IL28B gene-related SNPs were shown to be associated with good therapeutic outcomes in patients with HCV genotype 2 infection, following Peg-IFN plus ribavirin therapy for 24 weeks (2), when they did not achieve RVR (19). Thus, the significance of the serum HCV-RNA-negative period should be further evaluated in patients with $\mathrm{HCV}$ genotype 2 infection in relation to the alleles of IL28B gene-related SNPs. Such an approach merits

Table 5. The Outcome of Pegylated Interferon Plus Ribavirin Therapy Depending on Virological Response in Chronic Hepatitis Patients with HCV Genotype 2 in the Validation Cohort

\begin{tabular}{|c|c|c|c|}
\hline \multirow{3}{*}{$\begin{array}{l}\text { serum HCV-RNA titers } \\
\text { during the therapy }\end{array}$} & \multicolumn{3}{|c|}{ SVR rate $(\%)$} \\
\hline & \multicolumn{2}{|c|}{ duration of the therapy } & \multirow{2}{*}{$\begin{array}{l}<\text { weeks }> \\
25 \text { to } 50\end{array}$} \\
\hline & 11 to 20 & 21 to 24 & \\
\hline HCV-RNA $<1.7 \mathrm{Log} \mathrm{IU} / \mathrm{mL}$ at 4 weeks & $1 / 1(100)$ & $22 / 25(89)$ & $8 / 9(89)$ \\
\hline undetectable at 4 weeks* & $1 / 1(100)$ & $18 / 19(95)$ & $0 / 0$ \\
\hline detectable at 4 weeks* & $0 / 0$ & $4 / 6(67)$ & $8 / 9(89)$ \\
\hline $\begin{aligned} \text { HCV-RNA } & \geq 1.7 \mathrm{Log} \mathrm{IU} / \mathrm{mL} \text { at } 4 \text { weeks } \\
& <1.7 \mathrm{Log} \mathrm{IU} / \mathrm{mL} \text { at } 8 \text { weeks }\end{aligned}$ & $0 / 1(0)$ & $1 / 1(100)$ & $9 / 11(82)$ \\
\hline
\end{tabular}


consideration to improve the therapeutic efficacy of Peg-IFN plus ribavirin therapy, especially in patients with HCV genotype 2 infection, since novel direct-acting antiviral drugs, such as protease inhibitors, can, at present, be applied for combination therapy only in patients with $\mathrm{HCV}$ genotype 1 infection in Japan.

\section{Conclusion}

Prolonged Peg-IFN plus ribavirin therapy of the serum HCV-RNA-negative (less than $1.7 \mathrm{Log} \mathrm{IU} / \mathrm{mL}$ ) period for $\geq 17$ weeks may increase the SVR rate in chronic hepatitis patients with HCV genotype 2.

\section{Author's disclosure of potential Conflicts of Interest (COI).}

Satoshi Mochida: Honoraria, Chugai Pharmaceutical CO., LTD., MSD, Dainippon Sumitomo Pharma Co., Ltd., and Toray Industries, Inc.; Research funding, Chugai Pharmaceutical CO., LTD., MSD, Dainippon Sumitomo Pharma Co., Ltd., and Toray Industries, Inc.. Sumiko Nagoshi: Honoraria, Toray Industries, Inc.

\section{Acknowledgement}

We thank Dr. Eiichi Sekiduka (National Institute of Saitama Hospital), Dr. Chiaki Kawamoto (Nippon Medical School), Dr. Hiroshi Miyake (Kasukabe Shiritsu Hospital), Dr. Hirotsugu Fukuya (Saiseikai Kurihashi Hospital) and Dr. Koji Yakabi (Saitama Medical Center) for their advices to organize the Saitama Peg-IFN Study Group. We also thank Dr. Ryuichiro Araki (Community Health Science Center, Saitama Medical University) for his kind suggestions for statistical analysis.

\section{References}

1. Fried MW, Hadziyannis SJ, Shiffman ML, Messinger D, Zeuzem $\mathrm{S}$. Rapid virological response is the most important predictor of sustained virological response across genotypes in patients with chronic hepatitis C virus infection. J Hepatol 55: 69-75, 2011.

2. Sakamoto N, Nakagawa M, Tanaka Y, et al. Association of IL28B variants with response to pegylated-interferon alpha plus ribavirin combination therapy reveals intersubgenotypic differences between genotypes 2a and 2b. J Med Virol 83: 871-878, 2011.

3. Mangia A, Santoro R, Minerva $N$, et al. Peginterferon alfa- $2 b$ and ribavirin for 12 vs. 24 weeks in HCV genotype 2 or 3. N Engl J Med 352: 2609-2617, 2005.

4. Buti M, Lurie Y, Zakharova NG, et al. Randomized trial of peginterferon alfa-2b and ribavirin for 48 or 72 weeks in patients with hepatitis $\mathrm{C}$ virus genotype 1 and slow virologic response. Hepatology 52: 1201-1207, 2010.

5. Berg T, von Wagner M, Nasser $\mathrm{S}$, et al. Extended treatment duration for hepatitis $\mathrm{C}$ virus type 1 : comparing 48 versus 72 weeks of peginterferon-alfa-2a plus ribavirin. Gastroenterol 130: 1086-1097,
2006.

6. Mangia A, Minerva N, Bacca D, et al. Individualized treatment duration for hepatitis $\mathrm{C}$ genotype 1 patients: A randomized controlled trial. Hepatology 47: 43-50, 2008.

7. Ferenci P, Fried MW, Shiffman ML, et al. Predicting sustained virological responses in chronic hepatitis $\mathrm{C}$ patients treated with peginterferon alfa-2a (40 KD)/ribavirin. J Hepatol 43: 425-433, 2005.

8. Yu ML, Dai CY, Huang JF, et al. A randomised study of peginterferon and ribavirin for 16 versus 24 weeks in patients with genotype 2 chronic hepatitis C. Gut 56: 553-559, 2007.

9. Andriulli A, Mangia A, Iacobellis A, Ippolito A, Leandro G, Zeuzem S. Meta-analysis: the outcome of anti-viral therapy in HCV genotype 2 and genotype 3 infected patients with chronic hepatitis. Aliment Pharmacol Ther 28: 397-404, 2008.

10. Slavenburg S, Weggelaar I, van Oijen MG, Drenth JP. Optimal length of antiviral therapy in patients with hepatitis $\mathrm{C}$ virus genotypes 2 and 3: a meta-analysis. Antivir Ther 14: 1139-1148, 2009.

11. Inoue $\mathrm{Y}$, Hiramatsu N, Oze T. Factors affecting efficacy in patients with genotype 2 chronic hepatitis $\mathrm{C}$ treated by pegylated interferon alpha- $2 b$ and ribavirin; Reducing drug doses has no impact on rapid and sustained virological responses. J Viral Hepatol 17: 336-344, 2010.

12. Pearlman BL, Ehleben C, Saifee S. Treatment extension to 72 weeks of peginterferon and ribavirin in hepatitis c genotype 1infected slow responders. Hepatology 46: 1688-1694, 2007.

13. Manns MP, McHutchison JG, Gordon SC, et al. Peginterferon alfa-2b plus ribavirin compared with interferon alfa- $2 b$ plus ribavirin for initial treatment of chronic hepatitis $\mathrm{C}$ : a randomised trial. Lancet 358: 958-965, 2001.

14. Tanaka Y, Nishida N, Sugiyama M, et al. Genome-wide association of IL28B with response to pegylated interferon-alpha and ribavirin therapy for chronic hepatitis C. Nat Genet 41: 11051109, 2009.

15. Ge D, Fellay J, Thompson AJ, et al. Genetic variation in IL28B predicts hepatitis $C$ treatment-induced viral clearance. Nature 461 : 399-401, 2009.

16. Suppiah V, Moldovan M, Ahlenstiel G, et al. IL28B is associated with response to chronic hepatitis $\mathrm{C}$ interferon-alpha and ribavirin therapy. Nat Genet 41: 1100-1104, 2009.

17. Akuta N, Suzuki F, Kawamura Y, et al. Predictive factors of early and sustained responses to peginterferon plus ribavirin combination therapy in Japanese patients infected with hepatitis $\mathrm{C}$ virus genotype $1 \mathrm{~b}$ : amino acid substitutions in the core region and lowdensity lipoprotein cholesterol levels. J Hepatol 46: 403-410, 2007.

18. Akuta N, Suzuki F, Sezaki H, et al. Association of amino acid substitution pattern in core protein of hepatitis $\mathrm{C}$ virus genotype 1b high viral load and non-virological response to interferonribavirin combination therapy. Intervirology 48: 372-380, 2005.

19. Mangia A, Thompson AJ, Santoro R, et al. An IL28B polymorphism determines treatment response of hepatitis $\mathrm{C}$ virus genotype 2 or 3 patients who do not achieve a rapid virologic response. Gastroenterol 139: 821-827, 2010.

(C) 2012 The Japanese Society of Internal Medicine http://www.naika.or.jp/imindex.html 